\title{
Role of Calcium-Phosphate Ratio of Milk Formulae on Calcium Balance in Low Birth Weight Infants during the First Three Days of Life
}

\author{
M. MOYA ${ }^{(38)}$ AND E. DOMÉNECH \\ Department of Pediatrics, Faculty of Medicine, Hospital General y Clinico, University of La Laguna, Tenerife, \\ Canary Islands, Spain
}

\section{Summary}

Twenty-six low birthweight infants with no differences in the neonatal status were allocated into three groups. Group A (10 infants), Group B (8 infants), and C (8 infants) received formulae with $2.4,1.6$, and $4.1 \mathrm{Calcium} / \mathrm{Phosphate}(\mathrm{Ca} / \mathrm{Pi})$ ratio respectively. Formula $C$ was supplemented with calcium lactate $800 \mathrm{mg} /$ $\mathrm{kg} / \mathrm{day}$, which yielded $12.7 \pm 0.4 \mathrm{mg}$ of $\mathrm{Ca}$ and $0.04 \pm 0.002 \mathrm{mg}$ of Mg per each $100 \mathrm{mg}$ of salt (mean \pm S.D.). The osmolality of the $C$ formula before its administration was $361 \pm 52 \mathrm{mOsm} / \mathrm{kg}$. Balances (mean \pm S.D.) from the first feeding up to a period of 3 days were obtained. The intestinal product before any feeding contained: Ca, $1.3 \pm 0.6 \mathrm{mg} / \mathrm{kg} ; \mathrm{Mg}, 2.9 \pm 1.5 \mathrm{mg} / \mathrm{kg}$, and $\mathrm{Pi}, 1.5$ $\pm 2.3 \mathrm{mg} / \mathrm{kg}$. Calcium intake $(\mathrm{mg} / \mathrm{kg} / \mathrm{day})$ was $89.7 \pm 13.8$ for formula $A, 71.1 \pm 12.5$ for formula $B$, and $156.8 \pm 19.8$ for formula C. Their net retention $(\mathrm{mg} / \mathrm{kg} / \mathrm{day})$ was $50.8 \pm 15.9,39.3 \pm 12.8$ $(P<0.05)$, and $105.2 \pm 21.9(P<0.001)$ respectively.

Net retention of $P i$ was comparable in the three groups $(A, B$ and $C$ ) ranging $24.7-25.7 \mathrm{mg} / \mathrm{kg} / \mathrm{day}$. Small variations in intake are finely compensated by parallel urinary excretion (range 6.3$12.8 \mathrm{mg} / \mathrm{kg} /$ day).

Magnesium absorption did not show differences among the three formulae. The evolution of plasmatic values for magnesium was fairly normal in the three groups. Phosphatemia was significantly $(P<0.01)$ lower in group $A$ (lowest $P i$ containing formula) on the 3rd day. Patients on formula B (smaller Ca content) showed a mean blood calcium of $7.9 \mathrm{mg} / \mathrm{dl}$, which was significantly lower than in the other groups. In two instances, blood calcium was lower than $6.9 \mathrm{mg} / \mathrm{dl}(\mathrm{Z}=6.32 ; P<0.05)$. Net retention of calcium correlates positively with $\mathrm{Ca} / \mathrm{Pi}$ ratio $(r=0.82)$ and with absolute $\mathrm{Ca}$ intake $(r=0.84)$. Calcium lactate supplementation did not modify acid base equilibrium, lactatemia nor digestive tolerance.

\section{Speculation}

To prevent demineralization in the early postnatal period of preterm babies, the net retention of calcium could be improved more effectively by adding a calcium supplement to the formula rather than by decreasing its Pi content, even though both procedures lead to a comparable $\mathrm{Ca} / \mathrm{Pi}$ quotient.

If postnatal growth of the preterm infant parallels that in utero, then calcium intake should be sufficient to achieve a retention equivalent to that provided by the placenta; however, reality has demonstrated that this is a delusion $(12,20,29)$. The reduction in calcium supply after birth leads, apart from early hypocalcemia, to two abnormal conditions recently reevaluated. First, the presence of a late rickets when the birthweight of the very low birthweight infant doubles. Although this condition had been classically known, Kulkarni et al. (17) reported a $13 \%$ incidence of rickets in babies weighing less of $1.5 \mathrm{~kg}$ and receiving $500 \mathrm{IU}$ of vitamin D from the 10th day of life onwards. Second, a reduced calcium supply after birth can lead to a decreased bone mineralization after birth (32). The preterm infant needs 10 days to equal the bone mineral content he had at birth, as estimated by photon absorptiometry (19).

Nevertheless, blood calcium is maintained after the first days of life, at least since the use of new milk formulae has become general. But in the first 2-3 days of life, early neonatal hypocalcemia has an increased occurrence and gives rise to early $(35,36)$ and late $(13,24,28)$ complications.

The mechanism for the neonatal reduction of calcium gain is still unclear. Hormonal studies $(7,9,25,26,27)$ are not well defined as of yet and more investigation is required. Further research is also needed concerning polar metabolites of vitamin D in neonatal period (32).

The next point is to decide the best way to ensure a retention similar to that provided by the placenta. Supplementation with calcium lactate has two main effects: it prevents early neonatal hypocalcemia (20) and it improves the net retention of calcium, not only in the late neonatal period $(8,21)$ but also in the first 3 days of life (22).

The purpose of the present work is to assess whether calcium supplementation by itself during the first 3 days of life increases the net retention of calcium more effectively than would otherwise be obtained by an elevated $\mathrm{Ca} / \mathrm{Pi}$ value of formulae.

\section{PATIENTS, MATERIAL, AND METHODS.}

Twenty-six low birthweight infants with no clinical problems born in the hospital between December 1978 and June 1980, were allocated into three groups according to the different $\mathrm{Ca} / \mathrm{Pi}$ ratio of the formula. Their gestational age was assessed both by the last menstrual period of the mother and the Dubowitz method (10).

It ranged from 32-39 wk. Birthweights were between 1.9-2.4 $\mathrm{kg}$. Gestational age, birthweight, and age at balance scratch did not differ in the variance analysis among the three groups (Table 1). Both formulae were in agreement with ESPGAN's recommendations (6). According to the label, formula A (10\% dilution) contains: protein, $1.6 \mathrm{~g} / \mathrm{dl}(76.1 \%$ whey protein) and fat, $2.4 \mathrm{~g} / \mathrm{dl}$ (53.3\% saturated fatty acids). Formula B (10\% dilution ) contains: protein, $1.45 \mathrm{~g} / \mathrm{dl}(55 \%$ whey protein) and fat, $2.8 \mathrm{~g} / \mathrm{dl}(50.0 \%$ saturated fats). Estimated caloric intake for formula A, B and C respectively was, on the first day: $50.5 \pm 10.6,36.6 \pm 4.2$, and 33.8 $\pm 6.4 \mathrm{kcal} / \mathrm{kg}$. On the second day it was $54.0 \pm 11.4,50.6 \pm 9.8$ and $51.3 \pm 10.2 \mathrm{kcal} / \mathrm{kg}$ and on the third day: $67.4 \pm 7.5,61.8 \pm$ 6.7 , and $65.3 \pm 12.3 \mathrm{kcal} / \mathrm{kg}$. None of the formulae were supplemented with vitamin $D$. The mineral content (Table 2) yielded significant differences in the $\mathrm{Ca} / \mathrm{Pi}$ ratio, which was always within or above the range of 1.1-2 (5) and 1.2-2 (6) previously established. Group A (10 infants) received a formula with $\mathrm{Ca} / \mathrm{Pi}$ 
quotient of 2.4. Group B (8 infants) received a formula with a 1.6 ratio, and Group $C$ ( 8 infants) received formula $B$, which was supplemented with $800 \mathrm{mg} / \mathrm{kg} /$ day of calcium lactate giving a final calcium/phosphate ratio of 4.1 . The differences in magnesium content of the reconstructed formulae are based on the presence of magnesium in the lactate salt. It was measured in eight instances, giving values, (when referred to $100 \mathrm{mg}$ of salt) of 12.75 $\pm 0.35 \mathrm{mg}$ for calcium, and $0.04 \pm 0.002 \mathrm{mg}$ for magnesium. This accounts for an extra supply of magnesium of $0.032 \mathrm{mg} / \mathrm{ml}$ when using formula $\mathrm{C}$, as shown in Table 2 . Because supplementation implies a rise in osmolality, calcium enriched formula has an increased osmolality. Nevertheless, it remains at the same level as in formula $\mathrm{A}$ when administered at $14 \%$ concentration, that is to say to a newborn older than 5 days.

Table 1. Neonatal status and hours of life when balances are started

\begin{tabular}{|c|c|c|c|c|c|c|}
\hline \multirow[b]{2}{*}{ Formula } & \multicolumn{3}{|c|}{ No. } & \multirow{2}{*}{$\begin{array}{c}\text { Gesta- } \\
\text { tional } \\
\text { age } \\
\text { (wk) }\end{array}$} & \multirow{2}{*}{$\begin{array}{c}\text { Birth } \\
\text { weight } \\
(\mathrm{kg})\end{array}$} & \multirow{2}{*}{$\begin{array}{c}\text { Balance } \\
\text { scratch } \\
\text { (h) }\end{array}$} \\
\hline & AGA & SGA & Total & & & \\
\hline A & 8 & 2 & 10 & $36.7 \pm 2.3^{1}$ & $2.2 \pm 0.2$ & $11.4 \pm 2.9$ \\
\hline B & 5 & 3 & 8 & $36.0 \pm 2.6$ & $2.1 \pm 0.2$ & $10.8 \pm 3.2$ \\
\hline $\mathrm{C}$ & 7 & 1 & 8 & $36.3 \pm 1.5$ & $2.2 \pm 0.2$ & $10.6 \pm 3.2$ \\
\hline \multicolumn{2}{|c|}{ F (Snedecor) } & & & NS & NS & NS \\
\hline
\end{tabular}

' Mean \pm S.E.

Table 2. Mineral content and osmolality of formula immediately before feeding

\begin{tabular}{cccccc}
\hline $\begin{array}{c}\text { Formula } \\
10 \%\end{array}$ & $\begin{array}{c}\mathrm{Ca} \\
(\mathrm{mg} / \mathrm{ml})\end{array}$ & $\begin{array}{c}\mathrm{Mg} \\
(\mathrm{mg} / \mathrm{ml})\end{array}$ & $\begin{array}{c}\mathrm{Pi} \\
(\mathrm{mg} / \mathrm{ml})\end{array}$ & $\begin{array}{c}\text { Osm } \\
(\mathrm{mOs} / \mathrm{kg})\end{array}$ & $\begin{array}{c}\mathrm{Ca} / \mathrm{Pi} \\
\text { ratio }\end{array}$ \\
\hline $\mathrm{A}$ & $0.83 \pm 0.11^{2}$ & $0.09 \pm 0.01$ & $0.35 \pm 0.04^{2}$ & $266.5 \pm 28$ & 2.40 \\
$\mathrm{~B}$ & $0.73 \pm 0.11^{4}$ & $0.08 \pm 0.02^{4}$ & $0.44 \pm 0.05$ & $285 \pm 35.4^{3}$ & 1.66 \\
$\mathrm{C}$ & $1.70 \pm 0.35$ & $0.11 \pm 0.01$ & $0.41 \pm 0.03$ & $361 \pm 52$ & 4.15 \\
\hline
\end{tabular}

${ }^{\mathrm{I}} n=78 ;$ mean $\pm \mathrm{S} . \mathrm{D}$.

${ }^{2} P<0.01$ between $\mathrm{A}$ and $\mathrm{B}$.

${ }^{3} P<0.01$ between $\mathrm{B}$ and $\mathrm{C}$.

${ }^{4} P<0.001$ between $B$ and $C$.
Methods. The balance technique (37) used (Fig. 1) was modified as follows: in the 6-12 $\mathrm{h}$ after birth and after performing the feeding test ( $5 \%$ glucose in demineralized water), a first formula, marked with red carmine was administered. From that moment on, 3 days of complete balance were counted. A new red carmine was then given to signal the end of balance. An aliquot part from each feeding, all stools, urine and regurgitations between the two red markers were collected. Vomitus and regurgitations were collected on a double disc of paper Wathman 541. In all cases values in urine were added to the fecal excretion because of their low content in calcium and magnesium. The marker's excretion time was measured at the beginning and at the end of balance. The time was considerably shorter in the latter case. The analysis of the fecal production from birth to the beginning of balance will be commented on later; however, it should be stated that daily weight was carefully recorded, being equal to or greater than that previously reported (18).

Aliquots from the diet, vomitus, regurgitations and faeces were dried and ashed at $450^{\circ} \mathrm{C}$ for $36 \mathrm{~h}$, then redissolved in $\mathrm{HCl}$. Urines were processed directly without ashing. Calcium and magnesium were measured by atomic absorption spectrophotometry. Phosphate was measured by Fiske and Subbarow's method. Blood pH, $\mathrm{PCO}_{2}$ and $\mathrm{tCO}_{2}$ were measured by means of a Radiometer apparatus. Lactate was measured by $\mathbf{L D H}$ (fully enzymatic) assay (15). Blood samples were drawn daily before the first morning feeding. Parental consent was obtained in all cases. All figures appearing in the text are expressed as mean \pm S.D. Comparison of means was made by Student's $t$ test. Linear and exponential curve fitting were performed. Discrete variable comparison test were used.

\section{RESULTS}

Results were not significantly different in appropriate-for-gestational age (AGA) and small-for-gestational age (SGA) infants, so comparisons were made only among groups $\mathrm{A}, \mathrm{B}$ and $\mathrm{C}$.

Meconium. The intestinal product, which exists before any feeding is initiated, needs (Table 3 ) considerably more time to be excreted $(20 \mathrm{~h})$ than faeces originated from food intake as measured from the $3 \mathrm{rd}$ day $(11 \mathrm{~h})$. Whole meconium weight is $7 \mathrm{~g} / \mathrm{kg}$ of body weight. The mineral content of the meconium is quite different from that of transitional or mature stools. Similar figures were observed in the first meconial stools of eight full term healthy

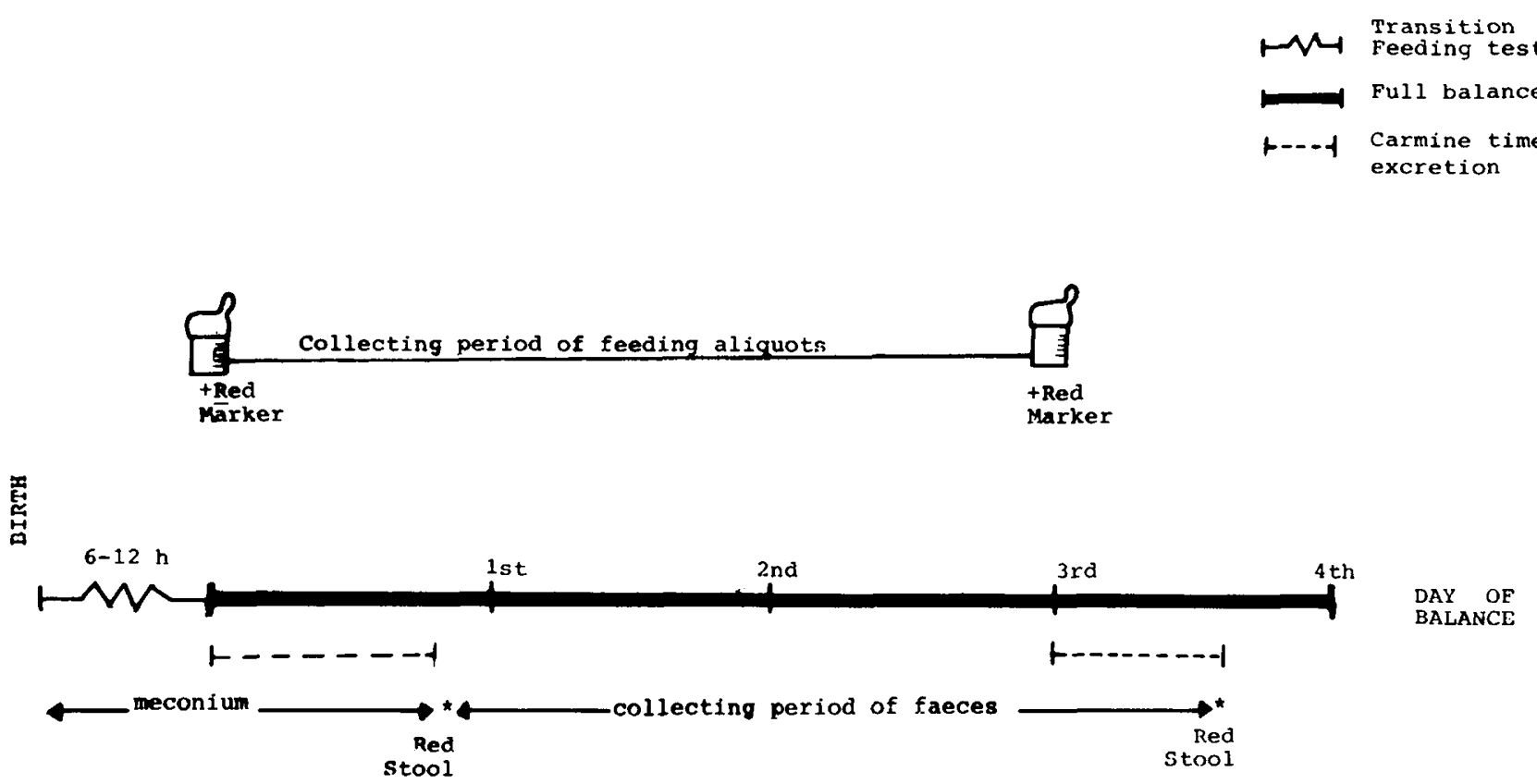

Fig. 1. Immediate neonatal balance. Immediately after the first feeding, urine and regurgitations are collected for a 72-h period. A sample is also taken from each bottle in order to quantify absorption. 
newborns. According to these data, the recollection of the first stained meconium perhaps need not be so important.

Regurgitation. In all our previous experience $(21,22)$, we have studied $\mathrm{Ca} / \mathrm{Pi}$ ratio of vomitus and regurgitations. In the present groups, (Fig. 2) the $\mathrm{Ca} / \mathrm{Pi}$ ratio of the regurgitated product (2nd column) for babies on regular formulae is slightly higher but not significantly, being 2.88 and 2.53 for $\mathrm{A}$ and $\mathrm{B}$ formulae respectively versus 2.40 and 1.66 of the original formula fed. In the group with supplemented formula, the ratio is almost similar (3.72). The number of vomitus and regurgitations did not increase significantly in the supplemented group $\left(\chi^{2}=0.22\right.$, not significant).

Urines. The output increased progressively throughout the 3 days. Considering the 26 babies all together, the volume of urine was $22.2 \pm 8.6 \mathrm{ml} / \mathrm{kg} / \mathrm{lst}$ day; $25.4 \pm 12.5 \mathrm{ml} / \mathrm{kg} / 2 \mathrm{nd}$ day and $29.8 \pm 7.1 \mathrm{ml} / \mathrm{kg} / 3 \mathrm{rd}$ day. Group A showed an excretion of $\mathrm{Ca}$, $0.29 \pm 0.08 \mathrm{mg} / \mathrm{kg} / \mathrm{day} ; \mathrm{Mg}, 0.06 \pm 0.01 \mathrm{mg} / \mathrm{kg} / \mathrm{day}$, and $\mathrm{Pi}, 6.9$ $\pm 2.0 \mathrm{mg} / \mathrm{kg} / \mathrm{day}$. In group B the excretion values were as follows: $\mathrm{Ca}, 0.16 \pm 0.04 \mathrm{mg} / \mathrm{kg} / \mathrm{day} ; \mathrm{Mg}, 0.05 \pm 0.003 \mathrm{mg} / \mathrm{kg} / \mathrm{day}$, and $\mathrm{Pi}$, $12.8 \pm 4.4 \mathrm{mg} / \mathrm{kg} /$ day and in group $\mathrm{C}: \mathrm{Ca}, 0.54 \pm 0.23 \mathrm{mg} / \mathrm{kg} /$ day; $\mathrm{Mg}, 0.12 \pm 0.07 \mathrm{mg} / \mathrm{kg} /$ day, and $\mathrm{Pi}, 6.3 \pm 2.7 \mathrm{mg} / \mathrm{kg} /$ day. All these figures were included in the excretion amounts in the balance diagrams because of their small quantity.

Table 3. Mineral content of meconium before it mixes with food residues ${ }^{1}$

\begin{tabular}{lcc}
\hline & $\begin{array}{c}\text { All babies } \\
n=27\end{array}$ & $\begin{array}{c}\text { Full term } \\
\text { control } \\
n=8\end{array}$ \\
\hline Excretion time $(\mathrm{h})$ & $20.8 \pm 8.6$ & $11.2 \pm 6.3$ \\
Weight $(\mathrm{g} / \mathrm{kg})$ & $6.9 \pm 3.3$ & $7.2 \pm 2.8$ \\
$\mathrm{Ca}(\mathrm{mg} / \mathrm{kg})$ & $1.3 \pm 0.6$ & $0.96 \pm 0.74$ \\
$\mathrm{Mg}(\mathrm{mg} / \mathrm{kg})$ & $2.9 \pm 1.5$ & $3.27 \pm 2.66$ \\
$\mathrm{Pi}(\mathrm{mg} / \mathrm{kg})$ & $1.5 \pm 2.3$ & $1.18 \pm 0.54$ \\
\hline
\end{tabular}

${ }^{1}$ Mear \pm S.D.
Intake and excretion of calcium, phosphate and magnesium. Balances of calcium and phosphate are represented in Figure 3. As shown in the first column block, intake differs significantly in the three groups being considerably higher in the supplemented group. The figures for formula A, B and C were $89.7 \pm 13.8,71.1$ \pm 12.5 , and $156.8 \pm 19.8 \mathrm{mg} / \mathrm{kg} /$ day, respectively. Despite the fact that excretion shows significant differences it does not parallel intake; therefore, the net retention differs significantly. The retained amounts for calcium in formula $\mathrm{A}, \mathrm{B}$ and $\mathrm{C}$ were $50.8 \pm$ $15.9,39.3 \pm 12.8$, and $105.2 \pm 21.9 \mathrm{mg} / \mathrm{kg} /$ day respectively, corresponding to an average absorption of $56.6 \%, 55.3 \%$ and $67 \%$. No baby fed on three formulae showed negative calcium balances. The net $\mathrm{Pi}$ retention was $24.7 \pm 3.6,25.7 \pm 3.9$, and $25.0 \pm 3.6$ $\mathrm{mg} / \mathrm{kg} / \mathrm{day}$, respectively.

Regarding magnesium balances (Fig. 4) (the diagram has been magnified 10 times), a smaller retention (expressed in $\mathrm{mg} / \mathrm{kg} /$ day) is observed in formula B $(4.6 \pm 1.8)$ than in both formulae A $(5.6$ $\pm 2.3)$ and $C(6.2 \pm 2.1)$, though it is not significant.

Number and appearance of faeces did not differ in the supplemented group from the others. Weight differences between supplemented and nonsupplemented groups were not significant $(\mathrm{t}$ $=1.22$ ). Their weight were: $6.23 \pm 2.1,6.76 \pm 2.40$, and $7.96 \pm$ $1.76 \mathrm{~g} / \mathrm{kg} /$ day for groups $\mathrm{A}, \mathrm{B}$ and $\mathrm{C}$ respectively.

Plasma measurements. Mineral concentration (Fig. 5). Magnesium evolution during the 3 days was fairly normal in all patients. Phosphatemia followed a more interesting sequence. On the third day, Group A (lowest Pi content formula) showed significantly lower values, 5.4 versus $6.5 \mathrm{mg} / \mathrm{dl}$ in group $\mathrm{B}(P<0.01)$. The sinus of the line plotted for calcemia on the 2 nd day was related not to phosphatemia $(r=0.1)$ but with decreased calcium intake, as will be discussed later. Patients on formula $\mathrm{B}$ developed hypocalcemia in two instances $(\mathrm{Ca}<6.9 \mathrm{mg} / \mathrm{dl})$, which according to a paired alternative is probably significant $(\mathrm{Z}=6.32 ; P<0.05)$.

In six babies belonging to group $C$, acid base equilibrium and lactatemia were assessed before and after the supplementation with calcium lactate was carried out. Values of $\mathrm{tCO}_{2}$ were $21.8 \pm$

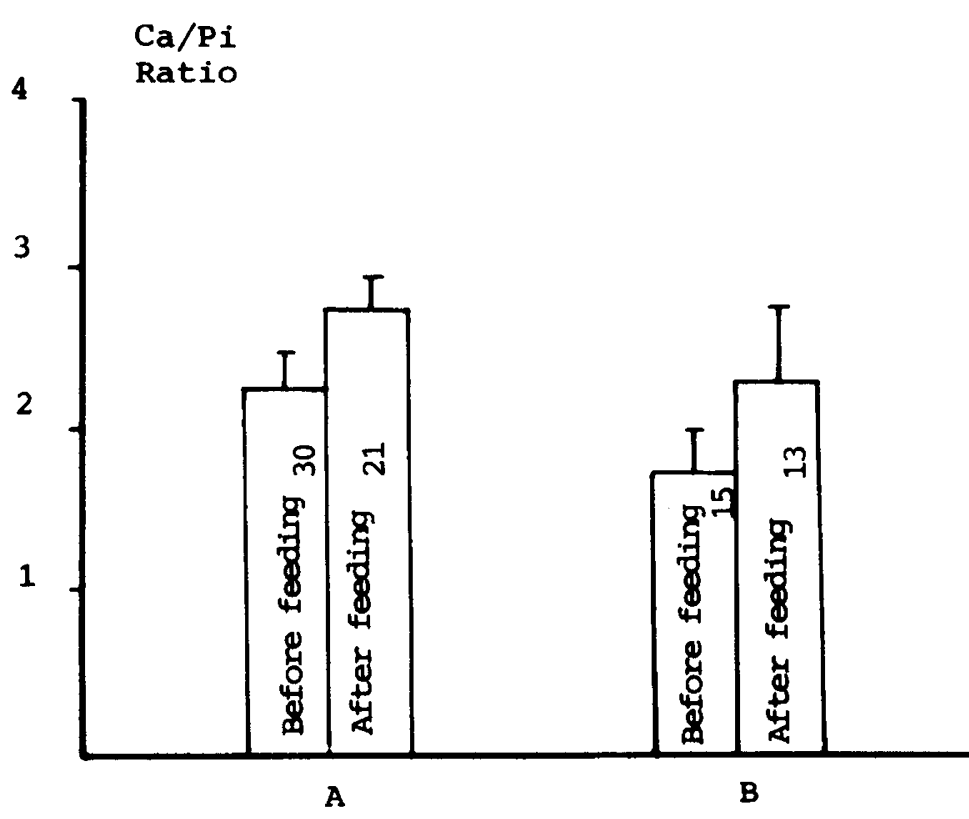

A

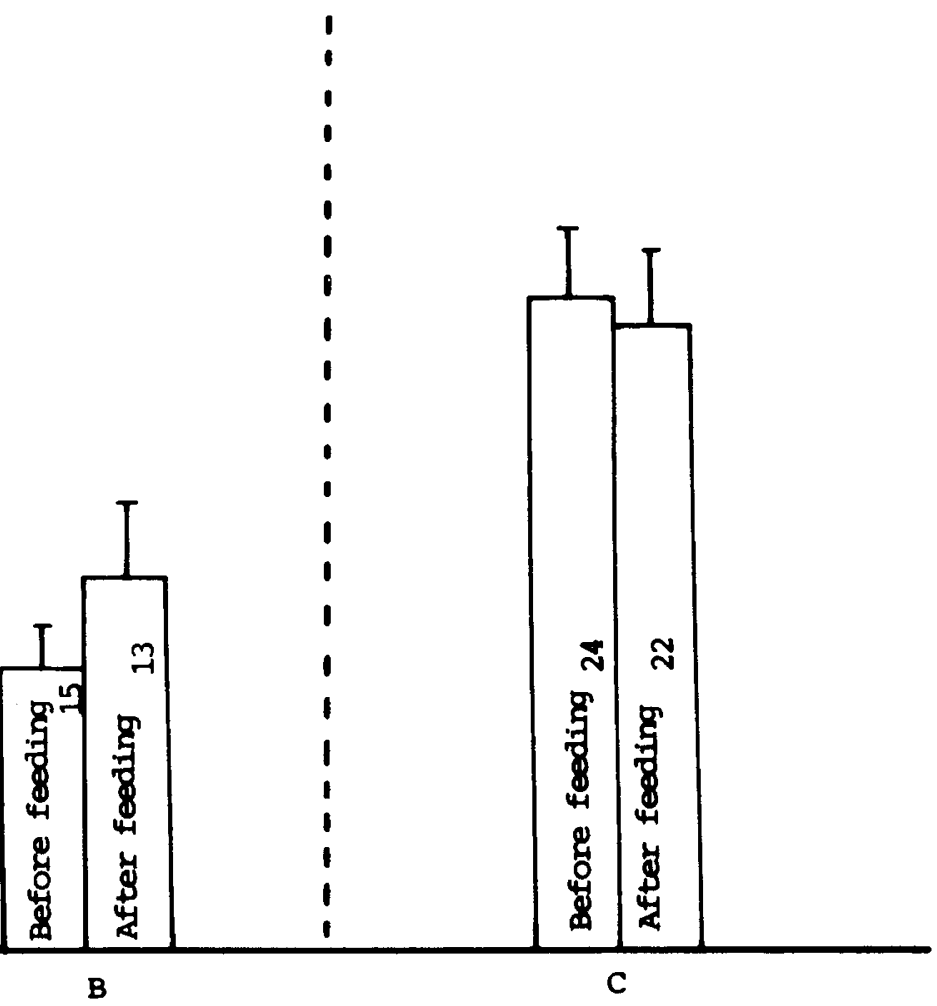

FORMULAE

Fig. 2. Calcium/phosphate ratio in regurgitated material. The first column refer to $\mathrm{Ca} / \mathrm{Pi}$ ratio of formula and the second one to that of the regurgitated material. Numbers inside columns stand for analyzed samples. 
FORMULAE

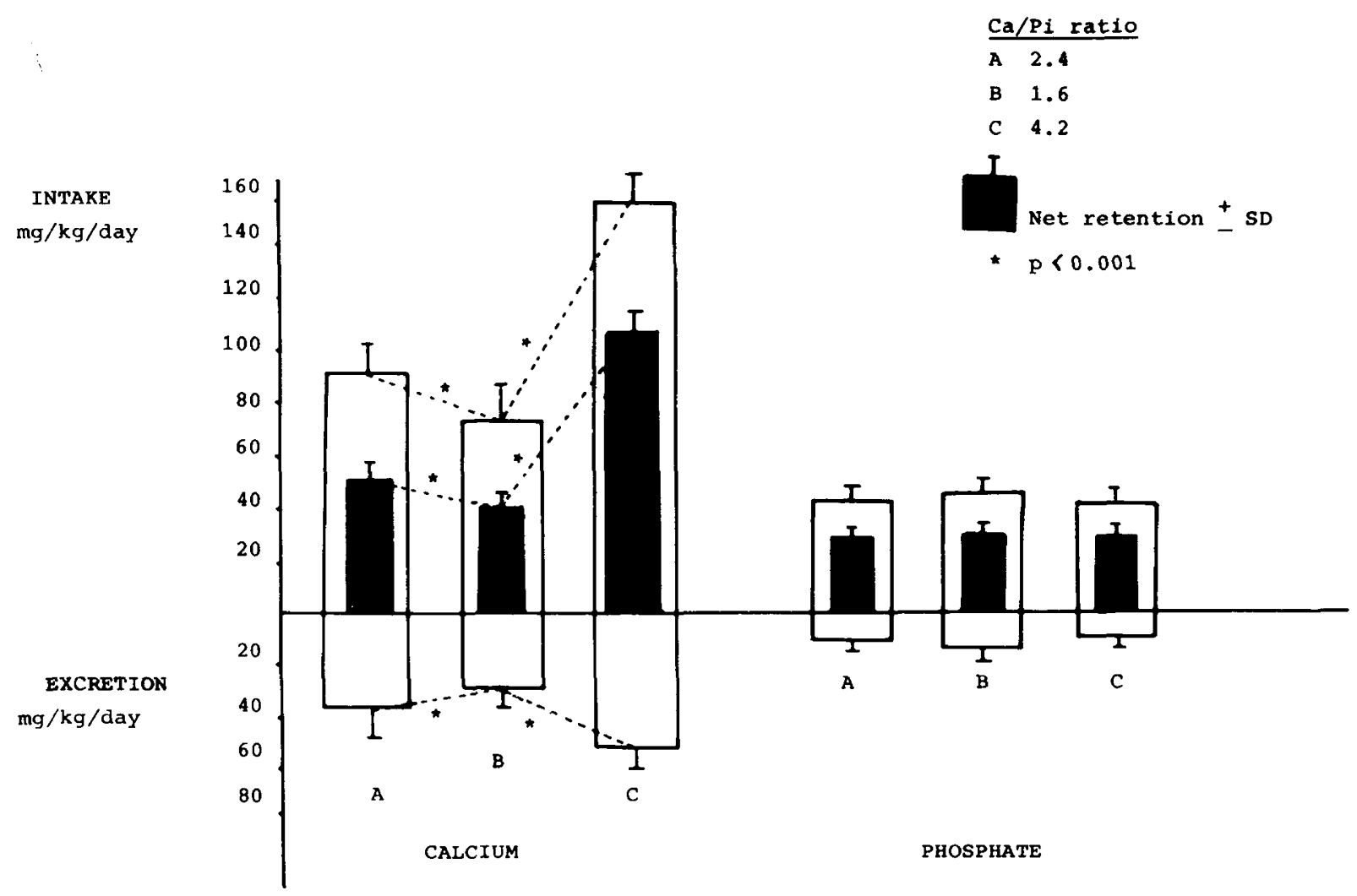

Fig. 3. Calcium and phosphate balances. Shaded area inside columns (above abscisa) represents net retention in the three formulae.

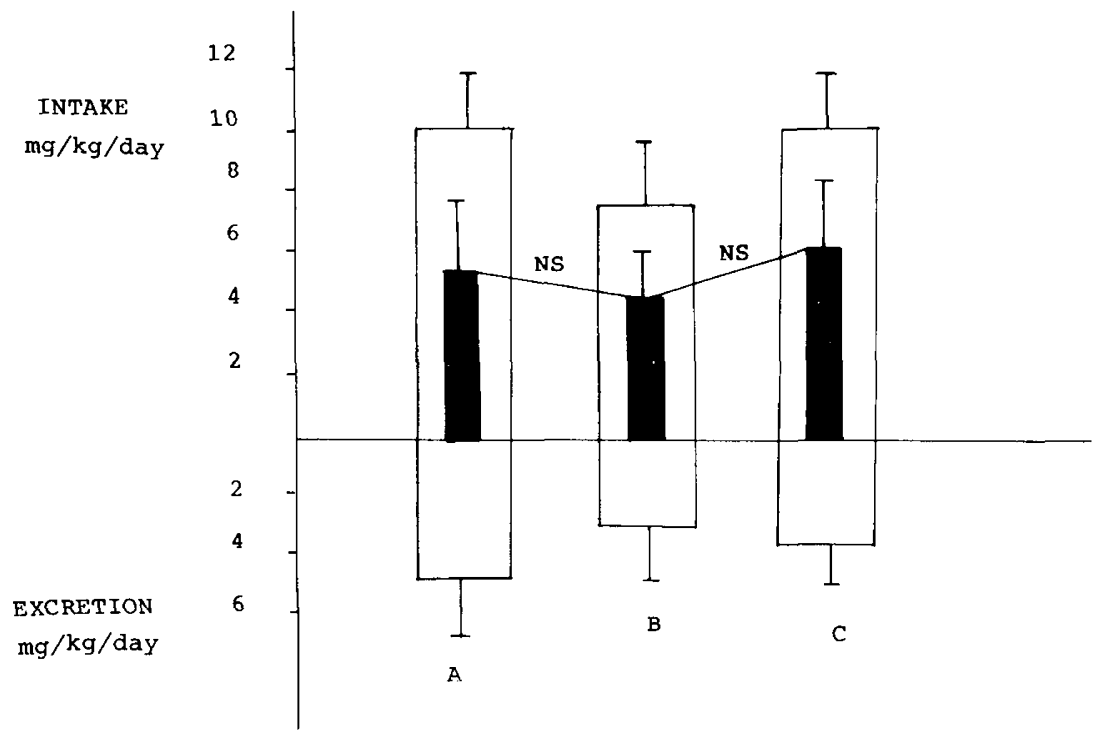

Fig. 4. Magnesium balance. Shaded area inside columns (above abscisa) represents net retention in the three formulae.

$2.4 \mathrm{mmole} /$ liter and $21.9 \pm 3.0 \mathrm{mmole} / \mathrm{liter}$ respectively. Lactic acid values, before and after, were $2.6 \pm 0.7 \mathrm{mmole} /$ liter and 2.8 $\pm 0.8 \mathrm{mmole} / \mathrm{liter}$, respectively. All these values, according to the paired $t$ test, do not reveal significant differences.

\section{DISCUSSION}

According to present knowledge $(12,29)$, in the last trimester of gestation the amount of calcium transferred to the fetus is nearly $20 \mathrm{~g}$, with an exponential gain that varies from $50 \mathrm{mg}$ /day at the $20 \mathrm{th}$ wk of gestation to $330 \mathrm{mg} /$ day at the $35 \mathrm{th} \mathrm{wk}$. This amount, at least in other mammals, is guaranteed provided the mother has not depleted her bone calcium stock, despite wide variations in calcemia (4). Therefore, a shorter gestation implies lesser mineralization of the fetal bones. Once the premature baby is born, placental supply is sharply cut off. Calcium normally needed depends now exclusively on the alimentary supply. Bone calcium reservoir can buffer the acute lack temporarily, but with consequences that will be analyzed later.

The amount of calcium retained from ingestion can be assessed by the balance technique. Some criticism has arisen against this procedure, but the bias error is more likely to occur if trace 


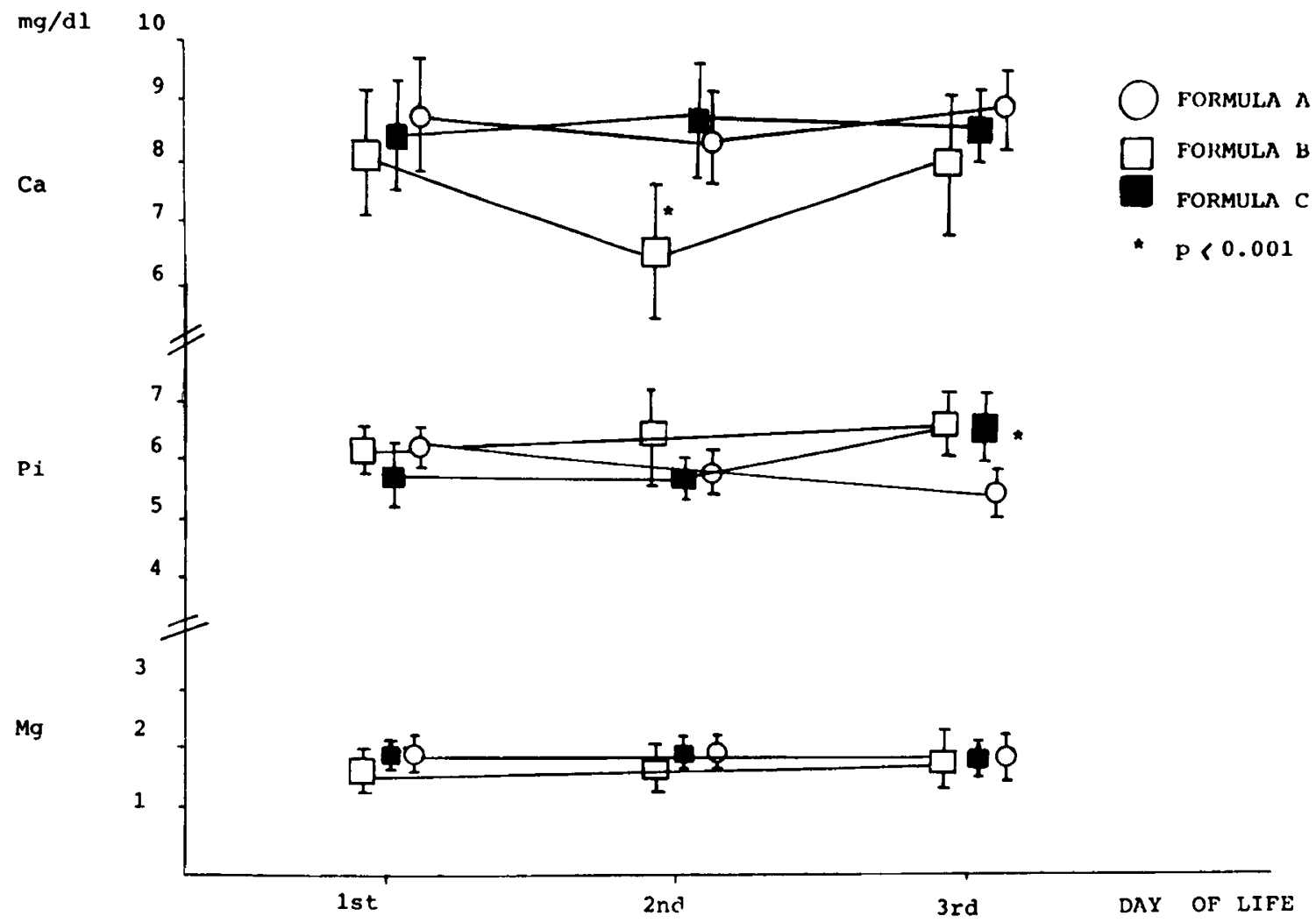

Fig. 5. Plasma concentrations in the first 3 days of life. Each point represents mean \pm S.D.

elements are studied during prolonged periods of time (16). Procedures based on photon absorptiometry have been experimented with in newborns (19). But as it occurs with neutron activation techniques (31), they are far from becoming part of the clinical routines. Taking into account the well known pitfalls, the conventional balance study (37) offers valuable information, even from the time of birth; thus, the net calcium retention figures obtained in the immediate neonatal period are, depending on the formulae they had been receiving, $51 \mathrm{mg} / \mathrm{kg} /$ day for formula $\mathrm{A}, 39 \mathrm{mg} / \mathrm{kg}$ / day for formula $\mathrm{B}$, and $105 \mathrm{mg} / \mathrm{kg} /$ day for formula $\mathrm{C}$. In a previous study (21), when B formula was used in similar babies who were 2 wk or older, the figures were almost doubled namely, $202(51.9 \%$ of the intake) and $69(40.8 \%$ of the intake) $\mathrm{mg} / \mathrm{kg} /$ day depending on whether formula was supplemented or not.

This neonatal rate of retention during the first days of life is less than that which other preterm newborns will retain a few days later according to another study using similar formulae $(29,30)$. This decrease in net retention needs further investigation. A deficiency in 1, $\alpha$-hydroxylation (33), with low levels of 1,25 $(\mathrm{OH})_{2} \mathrm{D}_{3}$ or an excess in the activity of the 24,25 hydroxylase (14), could account for this reduction (23). Another possibility is the secretion of calcium from the body into the gut which could account for $4-150 \mathrm{mg} /$ day. This is a particularly important problem since true intestinal calcium absorption is almost constant in premature babies despite a wide range of calcium intake $(2,34)$. In that sense, it is worthwhile to consider a slightly higher $\mathrm{Ca} / \mathrm{Pi}$ ratio in the regurgitated material when compared to the original formula. This may be due to some optimization of the ratio in the stomach. Recently it has been demonstrated (33) that in the first few days of life $1,25(\mathrm{OH})_{2} \mathrm{D}_{3}$ increases along with calcium in the diet. According to the results obtained in the present work, net retention of inorganic phosphate and magnesium are considerably reduced in the first 3 days of life when compared to those of the second wk. But apart from these considerations, the higher retention of calcium after the first days of life may be attributed to a higher intake of milk which increases roughly from 60 to $150-200$ $\mathrm{ml} / \mathrm{kg} /$ day.

Another aspect related to calcium supplementation is that the retained amount, $105 \mathrm{mg} / \mathrm{kg} / \mathrm{day}$, is closer to that supplied by the placenta, without noticeable side effects. The number of vomitus and/or regurgitations did not increase with the supplements nor did the weight of the stools. $\mathrm{tCO}_{2}$, and lactatemia values were unchanged. After a 3 days administration of calcium lactate at a rate of $800 \mathrm{mg} / \mathrm{kg} /$ day, no hypercalcemia was noticed in the supplemented groups, the highest figure being $10.1 \mathrm{mg} / \mathrm{dl}$. One thing also seems evident: the increased positiveness of calcium balance does not interfere with magnesium retention. Balance of inorganic phosphate deserves special comment because of its efficient handling by the kidney. Phosphate intake is higher in the group with formula B although not significant. But net retention remains much the same because of its greater urine excretion. As Barltrop et al. (2) pointed out, the level of $\mathrm{Pi}$ intake seems to play no special role in phosphate retention, unless figures twice as great as those of the present work were used. This is due to passive urinary excretion, which is determined by the differences between intake and retention. It is worth noting that the group on the highest phosphate intake showed the least calcium excretion. As it now stands, it is possible to state that hypocalcemia is a precocious manifestation of a more severe problem: demineralization.

In Figure 6, when the three groups are considered, it can be seen that a higher $\mathrm{Ca} / \mathrm{Pi}$ ratio provides a better retention of $\mathrm{Ca}$. From a ratio of 2 onwards, retention becomes lineal; thus it would seem advisable to recommend this minimum in proprietary formulae. Other aspects related to this problem are worth considering. When correlating net retention with absolute calcium intake, the coefficient $(r=0.84)$ is similar to that of the $\mathrm{Ca} / \mathrm{Pi}$ ratio $(r=$ 0.82 ). When compared to absolute $\mathrm{Pi}$ intake, the correlation is negative, although far from being significant.

On the basis of the present data, the importance classically attributed to the $\mathrm{Ca} / \mathrm{Pi}$ ratio in increasing retention should be reconsidered in favor of the total intake of calcium, which is particularly interesting in the first 3 days of life because the same results have been obtained in older neonates with a very accurate technique (2).

A review of data from Eck et al. (11) shows that mineralization, 


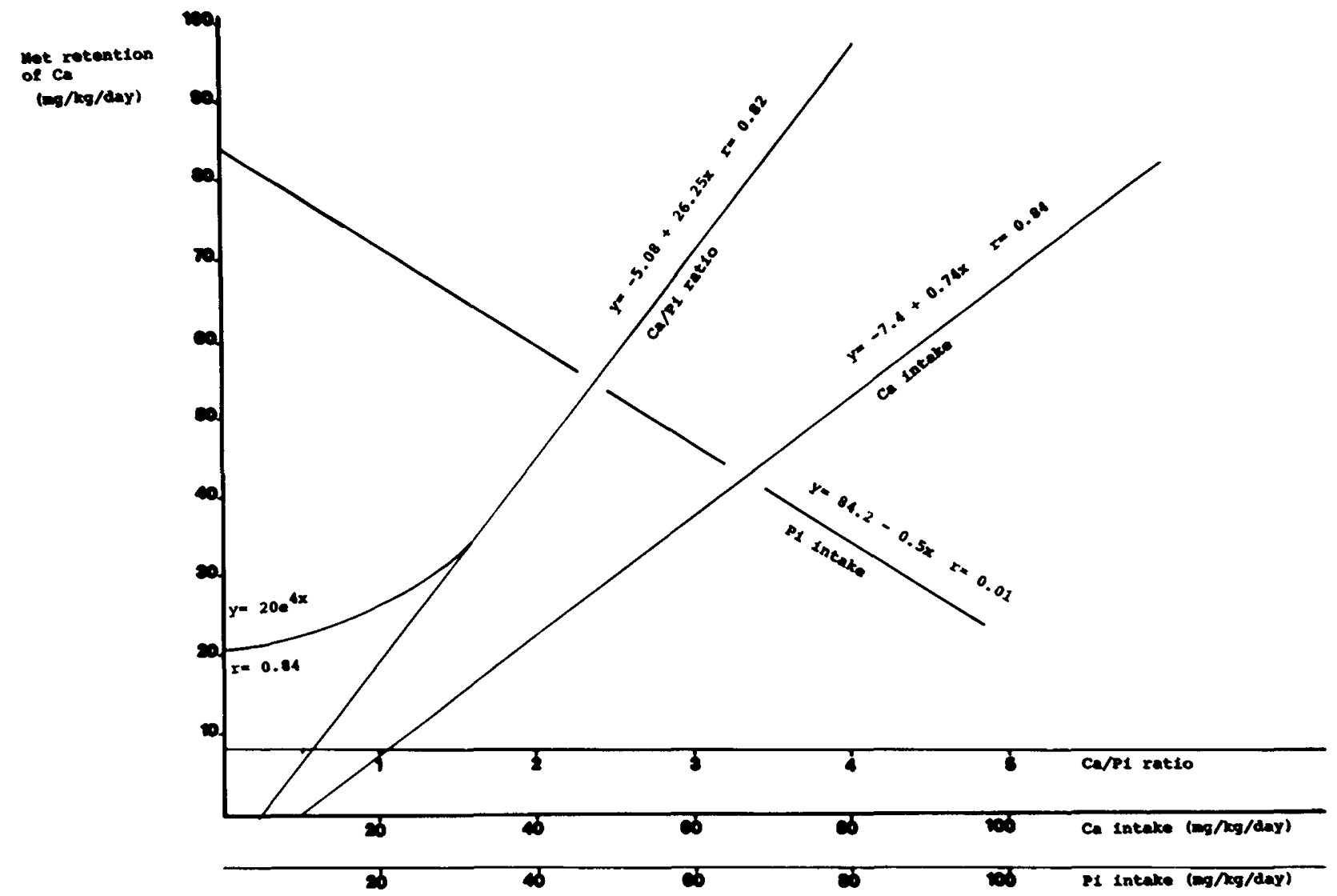

Fig. 6. Relationship between calcium retention with respect to (clockwise) formula's $\mathrm{Ca} / \mathrm{Pi}$ ratio, calcium intake and phosphate intake. All values obtained from the three groups are considered.

as measured by conventional $\mathrm{x}$-ray techniques, appears to be greater when using cow's instead of human milk on preterm babies. More recent studies $(1,8,29)$ using milk formulae show a net retention averaging $30-70 \mathrm{mg} / \mathrm{kg} /$ day on premature babies, who would otherwise be receiving $150 \mathrm{mg} / \mathrm{kg} /$ day via placental transfer. Thus, a large calcium shortage can be expected.

We measured the cortical index using a simple technique (3) in five premature AGA babies at birth, at two and at $6 \mathrm{wk}$ of age. We found results to fit perfectly in a curve with a negative exponent. Steichen et al. (32) demonstrated that as long as a daily calcium intake of $220-250 \mathrm{mg} / \mathrm{kg}$ could be maintained, extrauterine bone mineralization would be comparable to that intrauterine. These values are considerably higher than those normally achieved in the preterm although they are quite feasible in the full term babies due to a greater oral intake $(19,21)$.

There is a real challange, when trying to increase net retention of calcium in preterm babies. Whether this can be accomplished through an augmented oral intake or by facilitating its intestinal absorption or by reducing endogenous excretion remains to be elucidated.

\section{REFERENCES AND NOTES}

1. Barltrop, D. and Oppe, T. E.: Absorption of fat and calcium by low birthweight infants from milks containing butterfat and olive oil. Arch. Dis. Child, 48: 496 (1973).

2. Barltrop, D., Mole, R. H., and Sutton, A.: Absorption and endogenous faecal excretion of calcium by low birthweight infant on feeds varing contents of calcium and phosphate. Arch. Dis. Child., 52: 41 (1977).

3. Barnet, E. and Nordin, B. E. C.: The radiological diagnosis of osteoporosis: A new approach. Clinical Radiology, 11: 166 (1960).

4. Care, A. D., Dutton, A., Mott, J. C., Robinson, J. S., and Ross, R.: Studies on the transplacental calcium gradient. Physiol., 290: 19 (1979).

5. Committee on Nutrition. American Academy of Pediatrics. Commentary on breast feeding and infant formulas including proposed standards for formulae. Pediatrics, 57: 278 (1976).

6. Committee on Nutrition. European Society for Pediatric Gastroenterology and Nutrition (ESPGAN). Recommendations for the composition of an Adapted Formula. Acta Ped. Scand. Sup., 262: 12 (1977).
7. David, L. and Anast, C.: Calcium metabolism in newborn infants. J. Clin. Invest., 54: 287 (1974).

8. Day, G. M., Chance, G. W., Padde, I. C., Reilly, B. J., Park, E., and Sheepers, J.: Growth and mineral metabolism in very low birthweight infants. II. Effects of calcium supplementation on growth and divalent cations. Pediatr. Res., 9: 568 (1975).

9. Donovan, E. F., Tsang, R. C., Steichen, J. J., Strub, R. J., Chen, I. W., and Chen, M.: Neonatal hipermagnesium: effect on parathyroid hormone and calcium homeostasis. J. Pediatr., 96: 306 (1980)

10. Dubowitz, L. M. S., Dubowitz, V., and Golberg, C.: Clinical assessment of gestational age in the newborn infant. J. Pediatr.. 77: 1 (1970).

11. Eck, S., Gabrielsen, L. H., and Halvorsen, S.: Prematurity and rickets. Pediatrics, 20: 63 (1957).

12. Forbes, G. B.: Calcium accumulation by the human fetus. Pediatrics, 57: 976 (1976).

13. Forfar, J. O.: Biochemical fits in the newborn. Proc. Royal Soc. Med., 67: 375 (1974).

14. Goodwin, D., Noff, D., and Edelstein, S.: 24,25 Dihydroxy vitamin D is a metabolite of vitamin D essential for bone formation. Nature, 276: 517 (1978).

15. Gutmann, I. and Wahlefeld, A. W.: In: H. U. Bergmeyer Methoden der enzymatischen Analyze. 3rd Edition p. 1510 (Verlag Chemie Weinheim 1974).

16. Heroux, $O$. and Peter, D.: Failure of balance measurements to predict actual retention of magnesium and calcium by rats as determined by direct carcass analysis. J. Nutr., 105: 1157 (1957).

17. Kulkarni, P. B., Hall, R. T., Rhodes, P. G., Sheehan, M. B., Callenbach, J. C. Germann, D. R., and Abramson, S. J.: Rickets in very low-birthweight infants. J. Pediatr., 96: 249 (1980).

18. Lemoh, J. N. and Brooke, D. G.: Frequency and weight of normal stools in infancy. Arch. Dis. Child., 54: 719 (1979).

19. Minton, S.D., Steichen, J. J., and Tsang, R. C.: Bone mineral content in term and preterm appropriate-for-gestational-age infants. J. Pediatr., 95: 1037 (1979).

20. Moya, M. and Domenech, E.: Calcium intake in the first five days of life in the low birthweight infant. Arch. Dis. Child., 53: 784 (1978).

21. Moya, M. and Domenech, E.: Retention of calcium supplementation estimated by means of balances in the low birth weight infant. Pediatr. Res. (Abstract), 13: 75 (1979).

22. Moya, M. and Domenech, E.: Net retention of calcium, magnesium, and phosphate in the first three days of life in the low birthweight neonate. Pediatr. Res. (Abstract), 14: 171 (1980).

23. Navickis, R. J., Dial, D. K., Katzenellenbogen, B. S., and Nalbandov, A. V. Effects of gonadal hormones on calcium binding protein in chick duodenum. Am. J. Physiol., 237(5): E 409 (1979).

24. Nikiforuk, G. and Fraser, D.: Chemical determinants of enamel hypoplasia in 
children with disorders of calcium and phosphate homeostasis. J. Dent. Res., 58(8): 1014 (1979)

25. Pitkin, R. M.: Calcium metabolism in pregnancy: a review. Am. J. Obst. and Gynec., 121: 724 (1975).

26. Pitkin, R. M., Reynolds, W. A., Williams, G. A., and Hargis, G. K.: Calcium metabolism in normal pregnancy: a longitudinal study. Am. J. Obst. and Gynec., 133: 781 (1979).

27. Pitkin, R. M., Cruikshank, D. P., Schauberger, C. W., Reynolds, W. A., Williams, G. A., and Hargis, G. K.: Fetal calcitropic hormones and neonatal calcium homeostasis. Pediatrics, 66: 77 (1980).

28. Purvis, R. J., Mackay, G. S., Cockburn, F., Barrie, W. I. M. Wilkinson, E. M., Belton, N. R., and Forfar, J. O.: Enamel hypoplasia of teeth associated with neonatal tetany: manifestation of maternal vitamin $\mathrm{D}$ deficiency. Lancet, 2 : 811 (1973).

29. Shaw, J. C. L.: Evidence for defective skeletal mineralization in low birthweight infants: the absorption of calcium and fats. Pediatrics, 57: 16 (1976)

30. Southgate, D. A. T., Widdowson, E. M., Smites, B. J., Cooke. W. T., Walker, C. H. M., and Mathers, N. P.: Absorption and excretion of calcium and fat by young infants. Lancet, $1: 487$ (1969).
31. Spinks, T. J: Effects of size and composition of the body on absolute measurement of calcium in vivo. Physiol. Med. Biol., 24: 976 (1979).

32. Steichen, J. J., Gratton, T. L., and Tsang. R. C.: Osteopenia of prematurity: the cause and possible treatment. J. Pediatr., 96: 528 (1980).

33. Steichen, J. J., Tsang, R. G., Gratton, T. L., Hamstra, A., and De Luca, H. F.: Vitamin D homeostasis in the perinatal period: 1,25 Dihydroxi vitamin $D$ in maternal cord and neonate blood. N. Engl. J. Med., 302: 315 (1980).

34. Sutton, A., Mole. R. H., and Barltrop, D.: Urinary and faecal excretion of marker calcium $\left[{ }^{46} \mathrm{Ca}\right]$ by low birthweight infants. Arch. Dis. Child., 52: 50 (1977).

35. Troughton, T. K. and Singh, S. P.: Heart failure and neonatal hypocalcemia. Brit. Med. J., 4: 76 (1972).

36. Volpe, J.: Neonatal seizures. N. Engl. J. Med., 289: 413 (1973).

37. Widdowson, E. M.: Absorption and excretion of fat nitrogen and minerals from "filled" milks by babies one week old. Lancet, 2: 1099 (1965).

38. Requests for reprints should be addressed to: Professor Manuel Moya, Department of Pediatrics, Faculty of Medicine. Hospital General y Clinico, University of La Laguna, Tenerife, Canary Islands, Spain.

39. Received for publication March 4, 1981.

40. Accepted for publication February 3, 1981

\section{ANNOUNCEMENT}

The three-day course, first in Europe, will include plenary sessions, lectures and concomitant workshops covering a schedule of 50 hours. On the 4th day, October 17, there will be a round table open also to different staffs and families. This Course is designed primarily for pediatricians, geneticists, cytogeneticists, obstetricians, biologists and other scientists involved in Birth Defects. Active participation of the registrants will be encouraged in the workshops and by question-and-answers panels after lectures.

There will be ample opportunity for informal discussions. Poster sessions will be available.

The tuition fee, $\$ 130$, includes also 3 lunches and one dinner-dance in the Chianti countryside. Students and research fellows, $\$ 70$.

The Guest Faculty will consist of distinguished speakers from different countries: Cohen M. M. (Canada), Der Kaloustian V. M. (Lebanon), Emery A. (Scotland), Galjaard H. (Netherlands), German J. L. III (U.S.A.), Gorlin R. J. (U.S.A.), Hall J. G. (Canada), Harper P. S. (U.K.), Klein D. (Switzerland), Laurence K. M. (U.K.), Lindsten J. (Sweden), Mikkelsen M. (Denmark), Milunsky A. (U.S.A.), Motulsky A. G. (U.S.A.), Opitz J. M. (U.S.A.), Polani P. (U.K.), Rehder H. (Germany), Réthoré O. (Francia), Rimoin D. L. (U.S.A.), Sperling K. (Germany), Spranger J. (Germany), Weatherall J. A. C. (U.K.), Williamson R. (U.K.), Wolf U. (Germany).

Chairman:

M. FRACCARO, University of Pavia

Co chairmen:

A. FOIS, University of Siena

M. GIUSTI, Children Hospital Florence
Scientific Secretary:

\section{L. GIOVANNUCCI UZIELLI}

Human Genetics Service

Institute of Pediatrics

University of Florence

For further information contact:

Organizing Secretariat

Identification Genetic Syndromes

Ospedale Pediatrico A. Meyer

Via L. Giordano, 13

50132 Florence-Italy

Phone 055/57.59.53

\section{ANNOUNCEMENT}

20th Annual Meeting of the

Latin American Society for Pediatric Research

(S.L.A.I.P.)

"Club el Bosque" Carretera Central, Kilometro 30, Lima, Peru

October 3-6, 1982

For further information please contact:

Miguel A. Oliveros, M.D., President

Rio Moche 371

Pueblo Libre

Lima

Peru 